\title{
Western European Immigration Policy: Implications and Lessons for Russia
}

\author{
Mikhail Ivanovich Rykhtik ${ }^{1} \&$ Sergei Valerjevich Krivov ${ }^{1}$ \\ ${ }^{1}$ Lobachevsky State University of Nizhni Novgorod-National Research University, Nizhny Novgorod, Russia \\ Correspondence: Mikhail Ivanovich Rykhtik, Lobachevsky State University of Nizhni Novgorod-National \\ Research University, 603950, pr. Gagarina, 23, Nizhny Novgorod, Russia. E-mail: pr@unn.ru
}

Received: July 30, 2014 Accepted: September 30, 2014 Online Published: December 30, 2014

doi:10.5539/ass.v11n3p249 URL: http://dx.doi.org/10.5539/ass.v11n3p249

\begin{abstract}
This study explores the experience of West European migration policy and the opportunities for its application in Russia. The increase in migratory flows requires new approaches to policy-making. In addition experience address these problems illustrates the ambiguity of ways to their solution. The purpose of this study is to establish a causal relationship, identification of key trends in the development of this phenomenon as migration in the context of globalization, the analysis of potential challenges for Russia on the basis of foreign experience. Also addresses the issue of the possible impact of international sanctions against Russia for the further development of policies towards migrants.
\end{abstract}

Keywords: international migration, multiculturalism, integration policy

\section{Introduction}

The process of globalization has increases the number of migrants by almost three times in the last 50 years. If in 1960 the number of people living outside their country of birth was 75.5 million, in 2010 this figure is about 213.9 million. According to the UN experts, nowadays every 35th resident of the earth is an international migrant, while in developed countries is every $10^{\text {th }}$ resident. This goes together with the process of consolidation of ethnic communities. Not surprisingly, the number of Diasporas around the world is gradually growing because immigrants tend to maintain and, often, preserve their cultural traditions. According to some experts, today we can speak about the "diasporization of the world" (Friedman, 2005). The individual integration of immigrants into their host society is replaced by the collective integration.

There is no doubt that migrants have a major impact on host countries, changing their demographic structure, ethnic and religious composition. Migrants very often have a great impact on the values of host societies. There is also their growing influence on the foreign policy of host countries (Betrocci \& Strozzi, 2010). Large Diasporas possessing significant financial resources actively lobby not only their own interests but also the interests of those countries that historically are their Homeland (Barkan, 2012).

There is no common opinion in the scientific community on the impact of mass migration on a stable development of society. So, the very presence of migrants is seen as a destabilizing factor: there is strengthening of interethnic and religious conflicts in society (Hansen, 2003). At the same time, some believe that the influx of foreign labor accelerates the development and reducing the costs of infrastructure modernization for the economy of host countries. In addition, remittances of migrants play a significant role in increasing the national income of underdeveloped countries and help to eradicate the poverty (Smith, 1999).

There is no single approach to adaptation of immigrants. With regard to the so called "resettlement type countries" (the United States of America, Canada, Australia and New Zealand), where the basis of the political nation was formed by foreign settlers in the $19^{\text {th }}$ century. So far here is dominated old Anglo-Saxon system of nationality's granting based on the principle of jus soli (Latin: right of soil) (Burgess, 1967). At the turn of the $20^{\text {th }}$ century there were developed some adaptation mechanisms. But if Australia and Canada have stuck to the doctrine of multiculturalism and cultural diversity recognition, in the United States of America the concept of a "melting pot" with more vivid assimilation approach is more common. There is also a large influx of migrants in the countries of the Persian Gulf. So, the proportion of foreign-born residents in Qatar is $75 \%$, and in the United Arab Emirates is $71 \%$ (Kymlicka, 2012). Due to the principal migration flows originated from neighboring 
Islamic territories (Pakistan, Iran, Iraq and Palestine), the cultural gap between the local population and migrants is not so big. In addition, it preserves strong conservative tendencies in the policies of these states (Banting \& Kymlicka, 2012).

\section{Materials and Methods}

Most discussed in this sense is experience of European countries. Their monoculture foundation, the nation-state idea and jus sanguinis (Latin: right of blood) principle of citizenship since French Revolution, make difficult upgrade of policies toward migrants. After the Second World War, Europe faced a large migration influx from non-European countries (Sergounin, 1996). Several complicating Hansen`s approach, we identify four waves of migration to Europe in postwar period (Goodman, 2010). The first wave is connected with historical heritage. Some European countries such as the UK, Belgium and France had to receive migrants from their ex-colonies, so to say, "paying" colonial bills. In the early 1950s these countries already had a large proportion of migrants comparing with other European countries. The second wave is due to economic reasons. A number of countries had direct economic interests in immigrants as the cheap labor force. For example Germany since the early 1960s has concluded a number of bilateral agreements with the Mediterranean countries and Turkey in order to attract foreign workers. And in this case immigration can be both temporary and permanent. The third wave is associated with the adoption in most Western European countries legislation on family reunification and belongs to early 1970s. And finally, the forth wave which started in the late 1980s. It is connected with the political or humanitarian aspects. European countries declared a more "open" policy on developing countries and the states of the former Soviet bloc. To a large extent it happened under the influence of liberal sentiments prevailing in some European societies, for example, Sweden, Denmark, the Netherlands, Italy, Greece, etc. Our assumption is that each new migration wave causes the emergence of new patterns of adaptation of immigrants.

It's not a secret that immigrants are seldom warmly welcomed by the native population even in case of economic immigration. This in turn causes alienation on part of migrants. It is not surprising that some of the immigrants feel like outcasts. In turn, the peculiarities, for instance, of the Muslim "way of life" cause the rejection of newcomers by the native population. Unlike the US witch Islamic centers as a mechanism for the formation of loyal Islamic population (Koopmans, 2010), in Europe such institutions are not yet available. As a consequence, extremism is also nourished at schools and universities where there study young Muslim scholar refugees from the countries seized by interethnic and interreligious conflicts.

Political scientists single out five main approaches of migrants' integration: model of segregation, newly arrived worker, assimilation, multiculturalism, and the recently appeared model of civic integration or incorporation policy. Each of them has its strong and weak points depending on national interests.

The concept of segregation despite the negative association with apartheid in South Africa and Jim Crow lows in US is in fact special approach to migration policy. In this sense, the model of segregation is not considered as discrimination but as desire of authorities to maintain the separate settlement areas of migrants. The result of this separation becomes the formation of ethnic enclaves. The term "ethnic enclave" occurred in 1967 and it should be interpreted as an area populated by migrants, social infrastructure which aims to meet their own ethnic market and population (Joppke, 2012). Until the migration flows were on the rout "former colony - former colony metropolis" it doesn't create serious problems. The legacy of colonial period reflected in the awareness of the culture of the metropolis, including language.

Later starts migration for purely economic reasons, not related to the legacy of the colonial period. This has contributed to the emergence of "a newly arrived worker model", which is largely determined by the post war economic boom. This policy is based on the idea that immigrants worked for 2-3 years in the host country, and then return to their home country. So West Germany received hundreds of thousands of qualified and unqualified workers from Turkey and the countries of Mediterranean area during the period from 1955 to 1973. Similar policy was implemented in the Netherlands in the period from 1971 to 1981. It was assumed that under this policy there is no need for any efforts to integrate of immigrants into host society. As a result of reluctance to notice the stark contrast between the realty and policy has led to the fact that the Germans became known as "Parallelgesellschaften" or parallel society. It is not surprising that today the majority of researchers say a complete failure of this policy.

\section{Results}

The model of "multiculturalism" was launched in the 1970s. Originating in the West as the transition from the old forms of ethnic and racial hierarches to new values of democratic civil society, as noted by Kymlicka (Kymlicka, 2012), multiculturalism means the legitimization and political recognition of the ethnic diversity. Within the framework of this model it was initially supposed that migrants will become residents of the host 
country and the attitude to them should be similar to the attitude of its citizens, taking into account the specific features of their religion, ethnicity and cultural traditions.

The policy multiculturalism can be quantified. Multiculturalism Policy Index (MIPEX) was introduced in 2006 by K. Banting and W. Kymlicka (Banting \& Kymlicka, 2012). It consists of eight indicators, among them: legislative affirmation of multiculturalism, curriculum, mass-media, exemptions, dual citizenship, funding ethnic groups, bilingual education, and affirmative action policy. This model was put into effect in Great Britain $(5,5)$ and Belgium $(5,5)$ but above all, the doctrine of multiculturalism embodied in Sweden. This country has the highest rate among the European countries $(7,0)$, behind only Australia $(8,0)$ and Canada $(7,5)$ outside the continent. This is last but not least due to the long-dominant centre-left political forces in the political arena of the country. An even more striking example is Finland. While in 1980 the country had a "zero", in 2010 it came in second place in Europe $(6,0)$. It should be born in mind that the European countries lose out to countries of the New World on "affirmative action" indicator, which is unacceptable in Europe because it is regarded contrary to the principle of equality of all before the low. An exception is case of Belgium, in the Flemish community there is proportionality in legislation on employment. Despite the assurances of political leaders to abandon the policy of multiculturalism, index figures everywhere tend to grow. Even Norway, traditionally lowest European rate had already in $2010-3,5$. An exception is the Netherlands: 5,5 in 2000, and around 2,0 - in 2010. This is even lower than that of $1980(2,5)$. This significant reduction reflected in decrease of legislative affirmation, bilingual education and abolish of affirmative action policy. In particular in 2004 in this country were spun off many programs to ensure the representation of disadvantaged groups, including migrant workers in employment.

Implications of this model were ambiguous. Both Great Britain and the Netherlands failed to avoid violence, interethnic conflicts, growth of extremism and ethnic religious terrorism. Although the more tolerant Swedish society was able to avoid violence but also here anti-immigrant sentiments led to the success of right-wings radicals in the parliamentary elections. This model has its strengths. Her main feature is the formation of tolerant attitude toward migrants on pert of the host society. In practice, this finds expression in an effort to introduce a native-born population witch the cultural traditions of migrants. So, Alibhai-Brown outlined multiculturalism in Britain as "3S-model"(saris, samosas and steel drums) (Avralev \& Efimova, 2013). This approach has some sense as a host society largely determines behavior of migrants. However, the weak point of the model is that it does not focus on migrants themselves. It does not take into account the trend towards self-isolation or self-segregation of migrants.

In mid-1990s began disappointment in multiculturalism. There are tendencies towards assimilation and integration. The "assimilation" model spread in Europe in the mid-1990s. Unlike the United States, where this model is much more acceptable, this approach has been criticized in Europe. Criticism was based on doubts whether it is possible to include people from non-European countries in a homogeneous European society. Special emphasis as in the United States is put on the provision of civil rights. Migrants were viewed as individuals with each of whom the state concludes a "contract". Migrants were welcomed until they behaved as natives, observed local traditions and respected the institutions and legislation of the host country. The most well-known example of this very model is France, because the idea of civil society in this country already appeared in the $19^{\text {th }}$ century. This provided a good foundation for the formation of a new identity. The experience of France was followed by a number of other countries. So, in 1995 there was a move to a policy of assimilation in the Netherlands.

But the events taking place in France and other European countries demonstrated that the "assimilation" model doesn't help to avoid the problems at the levels of the second and third generations of former migrants. The level of social and economic integration of young descendants of the migrants of the 1950-1960s is still quite low. In addition, the growing popularity of radical politicians demonstrated the rejection of such a course. We suppose that the failure of this policy was caused by lack of effective tools for implementation of the policy of assimilation and acceptance in society regarding the objectives of this strategy (Avralev, 2013).

E. Barkan in 2007 proposed an "incorporation" model. Its essence is that a migrant originally fell into its ethnic enclave, where he has his initial adaptation to the host society (Barkan, 2012). If earlier ethnic enclaves were seen as a socially negative phenomenon (conservation of archaic forms of relations, shadow economy, etc.), now they are recognized as important institutions of migrants adaptation. Then the society and his institutions free it from ethnic enclave. It may be individual as well as within the whole group. In other matters, this approach is also associated with a number a difficulties. So it should be noted that ethnic groups and their leaders have generally opposed such a policy (Thurman \& Efimova, 2014). Nevertheless, this is an important step in rethinking the doctrine of multiculturalism and denial of unconditional admiration for him. 
Since the mid-2000s European countries are beginning to move to a policy of civic integration. The Netherlands became the first in adopting 2005 Act on Integration of Aliens (Wet inburgering in het buitenland). S. Goodman in 2010 has introduced the policy civic integration measurement index (CIVIX). She argues that "civic integration policy express the idea that successful incorporation into a host society rests not only on employment (economic integration) and civic engagement (political integration), but also on individual commitments to characteristic typifying national citizenship... country knowledge, language proficiency and liberal and social values" (Goodman, 2010). Calculation of the index is based on three main parameters: entry, settlement and citizenship. The scatter of data from 6.0 (Germany) to 0.0 (Sweden), show some sort scale integration policy.

\section{Discussion}

Given that the civic integration is often seen as an alternative of multiculturalism, it is interesting the correlation between these two strategies. K. Banting and W. Kymlicka (Banting \& Kymlicka, 2012) and next to them R. Koopmans (Koopmans, 2010) shall compare the two indices. So among the countries with highest integration index are Germany, Denmark and Austria (6.0,5.5 and 4.25 respectively). At the same time, it should be noted their low index of multiculturalism. By contrast, Sweden, Belgium and Finland have a low index of integration policy $(0.0,0.5$ and 1.0), with the highest rate of multiculturalism. To some extent, the United Kingdom is the exception, which has high level of both indexes.

This evidenced an experience of Australia and Canada, who have long embraced multiculturalism, and now successfully implement integration policies. European experience is other more ambiguous. It should be talk about the different options integration policies, which are more or less compatible witch multiculturalism. C. Joppke says about differences in integration policies across Europe (Joppke, 2007). Weak level of pressure on immigrants (low requirements for language and cultural knowledge), as well as the open nature of national identity are signs of "soft" model. As the Australian and Canadian experience, the model can be quite compatible witch a multicultural policies. In other words, both approaches do not seem mutually exclusive (Sniderman \& Hagendoorn, 2007).

In this regard, the experience of Russia and other post-Soviet countries is somewhat different, because mass migration has become a significant phenomenon only recently. In addition, among migrants dominate people from other republics former USSR who have the memory of a single state territory in the past (Koopmans, Statham, Giugni, \& Passy, 2005). It makes no talk of such a prominent cultural distance between migrants and domestic population. Whereas in Western Europe, the main problem lies in the fact that immigrants adapt to the dominant identity that emerged in $19^{\text {th }}$ - first half of $20^{\text {th }}$ century, the states of former USSR had not yet completed the process of nation-building. It is accompanied by a tendency to homogenize society and the growth of intolerance and xenophobic sentiments among titular population are not always related to the complexity of ethnic and cultural composition of population (Sniderman \& Hagendoorn, 2007). Not surprisingly, this region, with the exception of some local cases, while not yet developed effective mechanisms of adaptation of immigrants. However, the experience of countries of the European Union can be very rewarding.

Speaking about possible changes in immigration policy in the context of a sanctions regime imposed on Russia by the United States, Canada, the European Union and a number of others, it should be noted that among experts on this issue there is no consensus. Of course, that economic sanctions affect the majority macroeconomic indicators and especially the labor market, the state of which depends migration policy. However, it should be borne in mind that migration flows and policies to regulate them due to long-term factors. Also, do not underestimate the level of diversification of the Russian economy and to exaggerate the degree of its dependence on energy export. Thus, the largest share of Russian exports - crude oil - representing $39 \%$ of total foreign exchange from abroad. For comparison, the appropriate indicators in main oil-producing countries are: Saudi Arabia $-76 \%$, United Arab Emirates - 46\%, Iran - 72\%, Venezuela - 65\%. This may indicate a greater flexibility of Russian labor market even in the face of international sanctions. In addition, most of the migrants are not engaged in export-oriented industries, such as in the Gulf countries, but in the service industry, transport, construction, as well as in retail.

\section{Conclusion}

The world has enough of any criteria and indicators to judge the development of a country, but to see the perspective necessary to pay more attention to the fundamental sources of development, and primarily education (Avralev \& Efimova, 2013). Globalization of Higher Education is the most important part of the global innovation economy. And educational and research functions of universities is increasingly becoming a critical link in global innovation linkages (Efimova, 2013). 
The above models show that migration policies needed constant adjustment. In fact, it is an appropriate response to new global challenges. It seems that for Russia in this regard is rather important issue of the role and strategy of the government in the management of multiethnic environment (Avralev \& Efimova, 2014). Thus, it may be tested model, in which authorities are neutral with respect to the confessional and cultural differences as the spheres of private life (Grudzinskiy, 2004). The government only provides the framework to ensure equality of rights in the process of adaptation and integration of migrants into the host society. In addition, it will contribute the existence of cultural differences and will help to avoid the problem of the collision of identities. Probably, we should talk about legal pluralism, suggest the existence of legal rules for various groups in particular in the field of private (e.g., family) law (Avralev \& Efimova, 2013). But the question still remains open for most nation states whether it is possible to implement such a policy or not at the present moment (Ovcharov, 2008).

Thus, the problem of immigrants in Western Europe while experiencing a certain lack of initiatives. However, in the near future is the elaboration of such a strategy would be a priority the development of civil society and its institutions. One of the pivotal questions that are to be answered is whether the deficit of integration can be made up for by the initiatives of civil policy. In order to increase the role of civil society institutions in the process of migrants' integration experts suggest that emphasis should be put on the following measures. First of all, it is necessarily to abandon the common stereotypes and recognize the positive contribution to the solution of problems of national security. Then, it's necessary to cover the life of immigrants in mass media by improving their image among the "native" population. It's also important to actively involve immigrants, especially of the second and third generations, in the work of civil society institutions. There is also a need to create new civic institutions, in which will be the socialization of immigrants and their leaders will be brought up. In addition, we should talk about the full involvement of local population in the implementation of such initiatives.

\section{References}

Avralev N., \& Efimova, I. (2014). Global university rankings as indicators of the implementation of the integration process and competitive tool in the context of globalization of higher education. Life Sci J, $11(10), 648-652$.

Avralev, N. (2013). The Process of Merging Universities as One of the Key Tools to Improve Their Competitiveness and Strengthen the Rating Positions in the Global Market of Educational Services. World Applied Sciences Journal, 25(9), 1378-1382.

Avralev, N., \& Efimova, I. (2013a). The Role of the International University Network Organizations in the Innovative Development of Russia. Middle-East Journal of Scientific Research, 14(10), 1277-1291.

Avralev, N., \& Efimova, I. (2013b). University Rankings as a Tool to Enhance Competitiveness, Clustering and Transnational Governance of Higher Education in the Context of Globalization. Middle-East Journal of Scientific Research, 16(3), 357-361.

Banting, K., \& Kymlicka, W. (2012). Is the Really a Backlash Against Multiculturalism Policies? New Evidence from the Multiculturalism Policy Index. GRITIM Working Paper Series. Retrieved February 10, 2013, from http://www.upf.edu/gritim/_pdf/14_wp_banting_kymlicka.pdf

Barkan, E. (2012). Immigration, Incorporation and Transnationalism (p. 260). Transaction Publishers, New Brunswick.

Betrocci, G., \& Strozzi, Ch. (2010). The Evolution of Citizenship: Economic and Institutional Determinants. Journal of Law and Economics, 53(1), 95-136. University Chicago Press. http://dx.doi.org/10.1086/600080

Burgess, E. (1967). The Growth of the City: An Introduction to a Research Project. In R. E. Park, E. W. Burgess, \& R. D. McKenzie (Eds.), The City (pp. 47-62). Chicago: University of Chicago Press.

Efimova, I. (2013). Rankings as Tools to Promote Global Education Market. World Applied Sciences Journal, 25(10), 1400-1404.

Friedman, J. (2005). Diasporization, Globalization and Cosmopolitan Discourse. In A. Levy, \& A. Weingord (Eds.), Homelands and Diasporas (pp. 140-165). Stanford.

Goodman, S. (2010). Integration Recruitments for Integration`s Sake? Identifying, Categorizing and Comparing Civic Integration Policies. Journal of Ethnic and Migration Studies, 36(5), 753-772. http://dx.doi.org/10.1080/13691831003764300

Grudzinskiy, A. O. (2004). Project-oriented university: Professional entrepreneurial organization of the university (pp. 7-14). UNN Press. 
Hansen, R. (2003). Migration to Europe since 1945: Its history and Lessons. The political Quarterly, 74(Supplements 1), 25-38

Joppke, C. (2007). Transformation of Immigrant Integration. Civic Integration and Antidiscrimination in the Netherlands, France, and Germany. World Politics, 59, 243-73. http://dx.doi.org/10.1353/wp.2007.0022

Joppke, C. (2012). Citizenship and Immigration. In International Sociology (pp. 237-240).

Koopmans, R. (2010). Trade-Offs between Equality and Difference: Immigrant Integration, Multiculturalism and the Welfare State in Cross-National Perspective. Journal of Ethnic and Migration Studies, 36(1), 1-26. http://dx.doi.org/10.1080/13691830903250881

Koopmans, R., Statham, P., Giugni, M., \& Passy, F. (2005). Contested Citizenship. Immigration and Cultural Diversity in Europe (pp. 48-52). Minneapolis and London: University of Minnesota Press.

Kymlicka, W. (2012). Multiculturalism: Success, Failure, and the Future (pp. 42-44). Transatlantic Council on Migration. Project of the Migration Policy Institute.

Ovcharov, A. (2008). The Russian tourist industry: Trends and risks. Social Sciences, 39(3), 4-15.

Sergounin, A. A. (1996). An age of uncertainty: Building a post-cold war U.S. security strategy for East and Southeast Asia. East Asia, 15(2), 25-49.

Smith, J. (1999). Islam in America (p. 251). New York: Columbia University Press.

Sniderman, P. M., \& Hagendoorn, L. (2007). When ways of life collide (pp. 29-33). Princeton and Oxford: Princeton University Press.

Thurman, P. W., \& Efimova, I. (2014). Use of rankings to improve global competitiveness of Russian's higher education institutions and technology exports. Life Sci J, 11(11), 285-289.

\section{Copyrights}

Copyright for this article is retained by the author(s), with first publication rights granted to the journal.

This is an open-access article distributed under the terms and conditions of the Creative Commons Attribution license (http://creativecommons.org/licenses/by/3.0/). 